
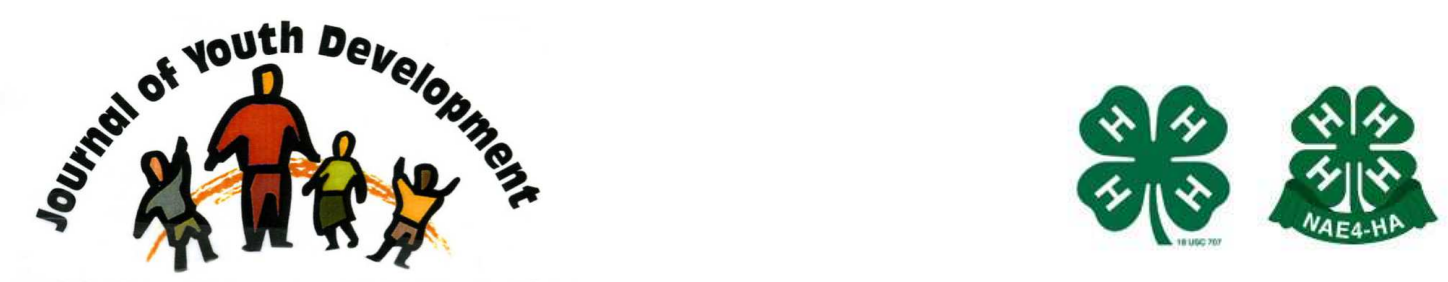

Bridging Research \& Practice

\title{
Parental Discussion about Personal Finances: Does it Make a Difference in the Amount of Debt Incurred?
}

\author{
Nancy C. Deringer \\ School of Family and consumer Sciences \\ University of Idaho \\ Moscow, ID \\ derringer@uidaho.edu
}




\title{
JOURNAL OF YOUTH DEVELOPMENT \\ bridging research and practice

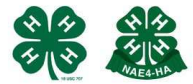

Bridging Research \& Practice

Volume 8, Number 1, Spring 2013

Article 130801FA004

\section{Parental Discussion about Personal Finances: Does it Make a Difference in the Amount of Debt Incurred?}

\author{
Nancy C. Deringer
}

University of Idaho

\begin{abstract}
Higher education costs have increased substantially over the past two decades and, therefore, student loan debt has increased as well. Studies have shown that one earns more money over one's lifetime if he/she has a four-year college degree. In fact, it is often substantially more depending upon one's profession. However, for some individuals, the costs of funding higher education may be confusing and often times overwhelming. A study was completed at a university in the pacific northwest $(n=778)$ which asked college students about their financial behaviors, credit card debt, student loan debt, discussions with parents, and in what topics or workshops they would like more information. Based on this data, faculty and graduate students from the school of family and consumer sciences and staff from the student financial aid office are creating workshops and curriculum to assist students in managing their debt and finances.
\end{abstract}

\section{The Situation: Preparing for Higher Education}

The current recession which began in December 2007 is impacting everyone, but it is especially challenging for young adults entering higher education. We know that education and income are closely related and therefore many young people have high aspirations for educational attainment (Shaklee, 2000). Future earning power may lead students to think a college degree is worth the debt incurred. According to a March 2007 report from the U.S. Census Bureau, adults with a bachelor's degree earned an average of $\$ 54,689$ in 2005 , while high school graduates earned an average of $\$ 29,448$. A bachelor's degree may be worth more than $\$ 25,000$ in increased annual income, but students must carefully choose their field of study and be realistic with how much they may earn. 
However, the rising costs of higher education may make a college degree prohibitive for many students. In 1981, students working full-time in the summer months could earn about twothirds of the full-time college costs for one year at a public institution. Twenty years later, students earning minimum wage would need to work full-time year-round to fund one year of education at a public school (Boushey, 2005). Therefore, many students are taking out sizeable government and private loans to pay their higher education.

The statistics confirm that student loan debt is continually increasing, and few students can afford college without multiple sources of financial aid. Two-thirds (65.56\%) of four-year undergraduate students graduating with a Bachelor's degree had education debt in 2007-2008, with an average debt of $\$ 23,186$-- an increase of $5.6 \%$ or $\$ 1,139$ a year a since $2003-2004$ (Kantorwitz, 2009). One quarter of undergraduate students borrow $\$ 24,936$ or more and one tenth borrow $\$ 35,213$ or more. College seniors who graduated in 2010 owed an average of $\$ 25,250$ in student loan debt, up 5\% from 2009 (Project on Student Debt, 2010). At a public university in the northwestern part of the United States, the 2007-2008 average student loan debt survey shows: $\$ 21,207$ for undergraduates, $\$ 39,937$ for graduate students and $\$ 55,619$ for law students (Student Financial Aid Report, 2009).

With the current recession, under employment and/or unemployment, there is also heightening concern about the increased student loan default rates. The following student loan national two-year cohort default rates are as follows: $2003-4.5 \%, 2004-5.1 \%, 2005-4.6 \%, 2006-$ $5.2 \%, 2007-6.7 \%, 2008-7.0 \%, 2009-8.8 \%$ to $9.1 \%$ for the 2010 two-year cohort (U.S. Department of Education, 2012). Student loans are generally considered "good debt" because it is an investment in oneself so that he/she has greater earning potential throughout one's lifetime. However, it is imperative that students understand the responsibility of paying back student loans, the different payment options available, and how this will affect one's budget during the payback process.

\section{Basic Financial Education and Debt}

The recession indicated that many Americans may be living beyond their means and do not have a firm grasp of basic financial concepts. Studies have shown that four in ten Americans are misusing and misunderstanding credit, and high school seniors on average answered less than fifty percent of financial competency questions correctly. (JumpStart Coalition, 2008). When examining credit card debt, $84 \%$ of undergraduate students had at least one credit card, and $40 \%$ of the graduating seniors carried a balance that averaged $\$ 4100$ (Sallie Mae, 2009). It appears that many youth as well as college students did not receive the adequate financial training necessary to make sound choices on how to spend, save and/or budget.

\section{Opportunities for Financial Education in High School}

Multiple public schools have responded to this lack of training and developed financial curriculums to be used with high school-aged students. Thirty-six states have implemented some type of personal finance training into their high school curriculums; however, only fourteen states require students to take a personal finance course as a high school graduation requirement. (Council for Economic Education, 2012). In addition to the response by organizations and public education, perhaps studies should examine the financial training and modeling (or lack of) occurring in the home between parent (or guardian) and the child. 


\section{Parent-Child Financial Education}

Many researchers agree that financial education needs to begin at an early age and that educating children on personal finance management at a young age will have positive, lasting effects on the rest of their lives (Lai, 2010; Livingstone, \& Lunt, 1992; Staten, 1993; Sumarwan, \& Hira, 1993). A study done by Pinto, Parente, and Palmer (2001) showed that lack of parental involvement in a child's finances can have serious implications on the amount of debt they will ultimately obtain. These researchers examined the relationship between parental involvement in credit card acquisition and the amount of credit card debt that college students accrue. They concluded that college students whose parents were involved in the acquisition of their credit cards have lower overall credit card debt than students who had no parental involvement at all. A similar study conducted by Goldberg (2005) examined variables that affected debt accumulation and concluded that while 70 percent of parents in his study had taught their teens how to do laundry, only 34 percent of them had taught their children how to balance a checkbook. And, only 34 percent of them had taught their children how credit card fees and interest work.

\section{The Study}

To address the issues of increasing student loan debt loads and default rates, while trying to understand how young adults are learning about personal finance, an interdisciplinary team was created between faculty and graduate student researchers at a university in the Pacific Northwest and the university's student financial aid office A mixed method research study was completed in 2010 which examined students' financial habits as well as their requests for additional training in financial topics.

A brief online survey was developed to capture undergraduate students' financial habits and needs for additional training workshops. Questions examined credit card debt, student loan debt, saving, budgeting, needs vs. wants, sources used to attend higher education, and financial issues or topics in which they would like more information. The university's institutional review board approved the survey. The university's registrar's office released 2000 randomly selected e-mail addresses. The response rate was 39\% $(n=778)$. Students were sent the survey by e-mail using QuestionPro in early 2010. The subject line of the e-mail read "Chance to win $\$ 50 . "$ Three reminder messages were sent weekly to the non-respondents in early 2010. The incentive to respond was having a chance to win one of four $\$ 50$ gift cards. Four e-mail addresses were drawn with winners notified by email. Data collected from these surveys will be help paint a picture of students' current financial situation. It will also be used in the design of future workshops to insure that students' financial issues and topics are addressed.

\section{Results of the Study}

Analysis using cross-tabulation indicated that $46 \%$ of $5^{\text {th }}$ year seniors, who have student loans, have $\$ 20,001$ or more in student loan debt with approximately $18 \%$ having more than $\$ 40,001$ (see table 1). 
Table 1

Reported Student Loan Debt by College Standing, $\mathrm{n}=778$

\begin{tabular}{|c|c|c|c|c|c|c|}
\hline & None & $<\$ 5000$ & $\$ 5001-10000$ & $\begin{array}{l}\$ 10001- \\
20000\end{array}$ & $\begin{array}{l}\$ 20001- \\
\$ 40000\end{array}$ & $\begin{array}{l}\text { More than } \\
\$ 40001\end{array}$ \\
\hline Freshman & $45.60 \%$ & $26.92 \%$ & $20.88 \%$ & $4.40 \%$ & $1.10 \%$ & $1.10 \%$ \\
\hline Sophomore & $40.70 \%$ & $15.70 \%$ & $25.58 \%$ & $12.21 \%$ & $5.23 \%$ & $0.58 \%$ \\
\hline Junior & $33.33 \%$ & $14.12 \%$ & $25.42 \%$ & $16.95 \%$ & $8.47 \%$ & $1.69 \%$ \\
\hline Senior & $33.52 \%$ & $6.25 \%$ & $18.75 \%$ & $21.02 \%$ & $17.05 \%$ & $3.41 \%$ \\
\hline $\begin{array}{l}\text { 5th Year } \\
\text { Senior }\end{array}$ & $14.71 \%$ & $3.92 \%$ & $6.86 \%$ & $28.43 \%$ & $28.43 \%$ & $17.65 \%$ \\
\hline
\end{tabular}

Fischer's Exact Test $\mathrm{p}<0.0001$

When students were asked to describe their financial situation, 51\% described their financial situation as shaky or disastrous while $49 \%$ described their situation as secure or comfortable (see Table 2).

Table 2

How Would You Describe Your Current Financial Situation?

\begin{tabular}{|l|l|}
\hline Secure & $8 \%$ \\
\hline Comfortable & $41 \%$ \\
\hline Shaky & $42 \%$ \\
\hline Disastrous & $9 \%$ \\
\hline
\end{tabular}

Other questions examined level of credit card debt, understanding needs vs. wants, budgeting, saving, sources used to fund higher education, and if they discussed financial issues with their parents. When looking at college standing and credit card debt, this study showed that of those students who had credit card debt, $77 \%$ had over $\$ 1000$ (see Table 3).

Table 3

College standing by credit card debt

\begin{tabular}{|l|r|r|r|r|r|r|r|l|}
\hline & None & $<\$ 500$ & $\begin{array}{l}\$ 501- \\
1000\end{array}$ & $\begin{array}{l}\$ 1001- \\
2500\end{array}$ & $\begin{array}{l}\$ 2501- \\
\$ 5000\end{array}$ & $\begin{array}{l}\$ 5001- \\
\$ 7500\end{array}$ & $\begin{array}{l}\$ 7500- \\
\$ 10000\end{array}$ & $\begin{array}{l}\text { More } \\
\text { than } \\
\$ 10000\end{array}$ \\
\hline Freshman & $86.81 \%$ & $9.34 \%$ & $1.10 \%$ & $1.10 \%$ & $1.65 \%$ & $0.00 \%$ & $0.00 \%$ & $0.00 \%$ \\
\hline Sophomore & $74.57 \%$ & $12.14 \%$ & $3.47 \%$ & $4.05 \%$ & $4.62 \%$ & $0.58 \%$ & $0.00 \%$ & $0.58 \%$ \\
\hline Junior & $58.66 \%$ & $13.97 \%$ & $10.06 \%$ & $7.82 \%$ & $4.47 \%$ & $2.79 \%$ & $1.12 \%$ & $1.12 \%$ \\
\hline Senior & $59.22 \%$ & $12.29 \%$ & $6.15 \%$ & $12.29 \%$ & $6.15 \%$ & $1.12 \%$ & $2.23 \%$ & $0.59 \%$ \\
\hline $\begin{array}{l}\text { 5th Year } \\
\text { Senior }\end{array}$ & $50.96 \%$ & $11.54 \%$ & $12.50 \%$ & $8.65 \%$ & $8.65 \%$ & $2.88 \%$ & $1.92 \%$ & $2.88 \%$ \\
\hline
\end{tabular}

Fischer's Exact Test $\mathrm{p}<0.0001$

When students were asked if they discussed credit card debt with their parents, Table 4 shows the results by how much credit card debt the student had. Twenty one percent of the students who did not discuss credit card debt with their parents had over $\$ 1000$ in debt. Of those students who discussed credit card debt with their parents, $13 \%$ had over $\$ 1000$ in debt. 


\section{Table 4}

Discussion with parents and credit card debt

\begin{tabular}{|l|r|r|r|r|r|r|r|l|}
\hline & None & $<\$ 500$ & $\begin{array}{l}\$ 501- \\
1000\end{array}$ & $\begin{array}{l}\$ 1001- \\
2500\end{array}$ & $\begin{array}{l}\$ 2501- \\
\$ 5000\end{array}$ & $\begin{array}{l}\$ 5001- \\
\$ 7500\end{array}$ & $\begin{array}{l}\$ 7500- \\
\$ 10000\end{array}$ & $\begin{array}{l}\text { More than } \\
\$ 10000\end{array}$ \\
\hline No & $58.58 \%$ & $11.24 \%$ & $9.47 \%$ & $0.65 \%$ & $8.88 \%$ & $0.59 \%$ & $0.00 \%$ & $0.59 \%$ \\
\hline Yes & $69.69 \%$ & $11.88 \%$ & $5.31 \%$ & $5.63 \%$ & $3.75 \%$ & $1.56 \%$ & $1.24 \%$ & $0.94 \%$ \\
\hline
\end{tabular}

Chi-square $=21.7983, p=0.0028$

Students were also asked if they discussed student loan debt with their parents. The data presented in Table 5 below showed that $20 \%$ of those with loans over $\$ 20,001$ did not discuss it with their parents.

Table 5

Discussion with parents and student loan debt

\begin{tabular}{|l|r|r|r|r|r|r|}
\hline & \multicolumn{1}{|l|}{ None } & $<\$ 5000$ & $\begin{array}{l}\$ 5001- \\
10000\end{array}$ & $\begin{array}{l}\$ 10001- \\
20000\end{array}$ & $\begin{array}{l}\text { \$20001- } \\
\$ 40000\end{array}$ & $\begin{array}{l}\text { More than } \\
\$ 40000\end{array}$ \\
\hline No & $26.51 \%$ & $13.86 \%$ & $25.30 \%$ & $13.86 \%$ & $14.46 \%$ & $6.02 \%$ \\
\hline Yes & $37.42 \%$ & $14.31 \%$ & $19.50 \%$ & $16.04 \%$ & $9.59 \%$ & $3.14 \%$ \\
\hline
\end{tabular}

Chi-square $=12.8841, p=0.0245$

Students were also asked if they discussed needs vs. wants with their parents but when compared to student loan or credit card debt, the data was not significant.

A qualitative question asked students to list what financial workshops or trainings would be most beneficial to them. Data were collected and grouped into the following themes. Table 6 presents the results.

Table 6

Most Common Themes Requested for Financial Workshops

\begin{tabular}{|l|l|}
\hline Frugal Living & $21 \%$ \\
\hline Budgeting & $17 \%$ \\
\hline School Costs & $15 \%$ \\
\hline Saving & $13 \%$ \\
\hline Student Loans & $10 \%$ \\
\hline Scholarships & $8 \%$ \\
\hline Credit Cards & $7 \%$ \\
\hline Debt & $5 \%$ \\
\hline Making Money & $4 \%$ \\
\hline
\end{tabular}

\section{The Response}

This study has shown that when students discuss student loans and/or credit cards with their parents, they have less debt. The importance of open communication about finances between parents and their children cannot be stressed enough. Using teaching opportunities before students leave for college may help students understand the responsibilities of living on their own, using credit responsibly, and paying back their loans. 
Educational programs are currently being developed in a variety of delivery formats. The goals are to have students think long term and understand the time value of money, reduce credit card debt and perhaps student loan debt, examine the actual costs of four-five years of higher education, learn how to budget their money, investigate all possible income sources to help finance their education, and find ways to live and play frugally.

One pre-financial aid workshop currently under development is: Your Financial Aid Cache. It is being developed by Family and Consumer Sciences graduate students who have taken personal finance courses, financial aid counselors and directors, with oversight from the family economics faculty. In this workshop, students will examine all possible income and resources available as well as examine ways to trim expenses. The intent is to have students focus on "pinching pennies," living frugally, and borrowing as little as possible. The program will be presented as a workshop to incoming students when they visit campus, as well as be available on-line and in hard copy formats to all students.

The curriculum currently being developed begins by looking at a realistic "big picture" of how much everything is projected to cost for the particular degree, e.g. undergraduate, graduate, and law. In addition to the broad expense categories of tuition/fees, books/supplies, room/board, and personal, students will need to be more specific by listing all possible expenses and breaking down the personal category.

Students will create a detailed monthly spending plan and include all of the above plus: housing costs such as rent on or off campus, utilities such as electricity and gas, water/sewer/trash, renters insurance, medical/dental/vision insurance, entertainment, cell phone/landline, cable TV, computer/internet expenses, loan payments such as a car payment, credit card payments, furniture/appliance payments, car insurance and registration, car maintenance, public transportation, food at home/food away from home, beverages, clothing, laundry, personal care items, banking fees, federal and state income taxes, recreation/sports/crafts/hobbies, vacations, household supplies, gifts, contributions, child care, life insurance, savings and/or retirement savings, investment, and misc.

In the next step students will consider all possible income sources and available resources. For income, students will list: money saved for college, help from parents/other relative, scholarships, grants, work-study, paid internship, income from part-time work, income from summer work, gift money, income tax refund, other source of income, and student loans (government subsidized and unsubsidized, and perhaps private loans). Student loans will be discussed thoroughly so they and their repayment options are understood by students. Available resources include utilizing things that are free or very low cost such as: using public transportation, bicycling, walking, enjoying parks and other outdoor recreation opportunities, etc.

Living frugally and focusing on ways to trim expenses will be one of the main highlights of the program. Examining needs vs. wants and listing multiple ways to cut expenses will be presented and written down by the students. This extensive list will be broken down into the categories of housing, telecommunications, transportation, food, shopping, entertainment, recreation, banking and credit, medical/dental expenses, insurance, childcare, and taxes. Students will also be asked to share their own ideas to add to the list. 
Other topics covered in the course will include basic financial education such as: understanding compounded interest and actual cost of loans, keeping a daily expense diary so you know where your money is going, reviewing expenses monthly, creating a filing system for recordkeeping, checking debit charges daily, balancing checking account weekly, eliminating overdraft fees, paying bills on time, eliminating late fees, using institution provided ATM machines, having an emergency savings, not carrying a balance on your credit card(s), and understanding the importance of saving early for retirement.

Another outcome from the collaborative effort between the family and consumer sciences department and the student financial aid office, and because of students' requests is the offering of new courses in consumer studies/family resource management. Curriculum changes are underway and include offering new courses in financial counseling and debt management and financial housing to meet the Accredited Financial Counselor and Planning Educator (AFCPE) certifications. The series of courses are currently being considered as a certificate program open to all majors across the university, yet offered through the family and consumer sciences department.

It is important for students to understand that government provided student loans are to be used as a vehicle for attending higher education. An investment in one's self to obtain higher paying jobs and increased earning potential over one's lifetime is powerful. However, this power needs to be fully understood. Parents and schools must both teach their children financial literacy skills before they attend higher education, so students can be good stewards with their money, learn how to live within their means, and be financially responsible consumers.

\section{References}

Boushey, H. (2005). Student debt: Bigger and bigger. Center for Economic and Policy Research. Retrieved March 29, 2008 from http://www.cepr.net

Council for Economic Education. (2012). Survey of the states.

Goldberg, K. (2005). Moving financial education for teens to the fore. World \& I, 20.

JumpStart Coalition for Personal Finance Literacy. (2002). JumpStart Questionnaire, Washington D.C.

Kantorwitz, M. (2009). Student loans. Retrieved July 31, 2009 from http://www.finaid.org

Lai, C. (2010). How financial attitudes and practices influence the impulsive buying behavior of college and university students. Social Behavior \& Personality: An International Journal, 38, 373-380.

Livingstone, S., \& Lunt, P.K. (1992). Predicting personal debt and debt repayment:

Psychological, social and economic determinants. Journal of Economic Psychology, 13, 111-134.

Pinto, M., Parente, D. \& Palmer, T. (2001). College student performance and credit card usage. Journal of College Student Development, 42, 49-58. 
Project on Student Debt. (2010). Student debt and the class of 2010. Oakland, CA.

Sallie Mae. (2009). How Undergraduate Students Use Credit Cards: Sallie Mae's National Study of Usage Rates and Trends.

Shaklee, H. (2000). Inventing adolescence: $20^{\text {th }}$ century concepts of youth development. Journal of Family and Consumer Sciences, 92 (5), 11-16.

Staten, M.E. (2002). The importance of financial literacy among college students. Hearing before the U.S. Senate Committee on Banking, Housing, and Urban Affairs, testimony before the 107th Congress.

Student Financial Aid Report. (2009). Moscow, ID: University of Idaho, Office of Student Financial Aid.

Sumarwan, U. \& Hira, T.K. (1993). The effects of perceived locus of control and perceived income adequacy on satisfaction with financial status of rural households. Journal of Family and Economic Issues, 14, 343-364.

U.S. Census Bureau, Current Population Survey. (2007). Educational attainment-people 18 years and old and over, by total money earnings in 2006, age, race, Hispanic origin, and sex. Annual social and economic supplement. PNC-04.

U.S. Department of Education. (2012). Two-year official default rates for schools. Retrieved September 30, 2012 from: http://www2.ed.gov/offices/OSFAP/defaultmanagement/cdr2yr.html

(C) Copyright of Journal of Youth Development Bridging Research and Practice. Content may not be copied or emailed to multiple sites or posted to a listserv without copyright holder's express written permission. Contact Editor at: patricia.dawson@oregonstate.edu for details. However, users may print, download or email articles for individual use.

ISSN 2325-4009 (Print); ISSN 2325-4017 (Online) 